University for Business and Technology in Kosovo

UBT Knowledge Center

UBT International Conference

2013 UBT International Conference

Nov 1st, 3:40 PM - 3:50 PM

\title{
Ethical relationship between stakeholders and stockholders and their moral rights on the corporation Differences
}

\author{
Besnik Skenderi \\ University for Business and Technology, besnik_skenderi@yahoo.com \\ Diamanta Skenderi \\ Tax Administration of Kosovo, diamanta_skenderi@yahoo.com
}

Follow this and additional works at: https://knowledgecenter.ubt-uni.net/conference

Part of the Business Commons

\section{Recommended Citation}

Skenderi, Besnik and Skenderi, Diamanta, "Ethical relationship between stakeholders and stockholders and their moral rights on the corporation Differences" (2013). UBT International Conference. 32. https://knowledgecenter.ubt-uni.net/conference/2013/all-events/32

This Event is brought to you for free and open access by the Publication and Journals at UBT Knowledge Center. It has been accepted for inclusion in UBT International Conference by an authorized administrator of UBT Knowledge Center. For more information, please contact knowledge.center@ubt-uni.net. 


\title{
Ethical relationship between stakeholders and stockholders and their moral rights on the corporation Differences
}

\author{
Besnik Skenderi ${ }^{1}$. Diamanta Skenderi ${ }^{2}$ \\ ${ }^{1}$ University for Business and Technology, Management and Business Administration \\ ${ }^{2}$ Tax Administration of Kosovo, Larger Tax Payers Unit \\ besnik_skenderi@yahoo.com ${ }^{1}$,diamanta_skenderi@yahoo.com ${ }^{2}$
}

\begin{abstract}
Abs tract: This paper is about ethical relationship between stakeholders and stockholders and their moral rights on the corporation. In a first part of this assignment author had provided a short description regarding costumer's rights and he had discussed different situations where customers and corporates are interacting. In this assignment author is suggesting that the exchange between the two must be voluntary and that consumers and customers have right to be properly informed for purchased products. Another discussed topic is advertisement that is closely linked with moralvalues and beliefs of shareholders. Regarding the ethics of owners and managers, author is raising the problem of misused power by some managers, while in the last part of the assignment author had discussed about employees' rights, duties and employee equity.
\end{abstract}

Keywords: Advertising, Customer, Consumers, Companies

\section{Customer and Consumers}

Costumers and consumers are affected, and influenced by information that they are receiving from sellers, corporations and from advertising. While customers are purchasing goods and services, consumers are using those goods and services. In these situation two interests exists, the interest of seller and interest of costumer. During this process of trade, sellers are protecting the interests of companies / shareholders, while law protects interests of costumers. However, there is an ethical issue, regarding the rights of consumers. Narveson, (1988) regarding the rights of buyers states that "On the view advanced here, this is a basic topic, for the buyer and seller both, we say, have a fundamental right to liberty. The exchange between the two must be voluntary" (p.48). From the perspective of seller in most cases the exchange process is voluntary, however from the buyer perspective there are many cases where compulsion is imposed. For example during the purchase of vehicle insurance buyers have opportunity so chose insurance company, but they are "legally forced" to purchase vehicle insurance. Sometimes compulsion is used by using fear and beliefs of consumers, for example, many companies are organizing "holly trips" to specific countries and regions. Costumers and consumer should be informed properly regarding the products and services that they are purchasing and using and they should not be misinformed.

Product description or description of goods is an important requirement, regarding this issue Narveson, (1988) states that" The requirement that whatever we do say not be false isn't quite the whole story, or at least is likely to be misinterpreted" (p.49).

During the process of purchase buyers need to be informed about criteria's and standards of goods that they are purchasing. This means that they should receive proper information regarding quality and expected lifetime of the purchased product. Customers and consumers are expecting that purchased products will perform according to the purchased price or they should have normal performance. However, the question remains "How much information does the seller have to supply to the buyer" (Narveson, 1988, p.50). Provided information can be regarding safety and risk that are related with a purchased product. Many companies are informing customers regarding risks that may occur while using the purchased products, however some companies are overreacting with provided information. Sometimes companies are assuming that common knowledge in enough, but because of risk that consumers can sue them in a court they are adding labels that sometimes can irritate some consumers, 
for example when a customer is purchasing kitchen knife, in a package there could be a warning that reminds costumer that product can be sharp.

One of the issues is also the unfair pricing, companies are using their market position to overcharge customers, and in most cases, this happens because of monopolistic position of companies. For example in Kosovo (country where author is living) the electricity is more expensive during the winter, and if customer is spending more than $1000 \mathrm{~kW}$ per month he will be charched with $50 \%$ higher price.

\section{Advertising}

Corporates are communication with costumers through advertisement, however this is one-way communication and customers are receiving selected information regarding products and services that are offered by those corporations. Regarding the advertisement Narveson, (1988), discusses that the advertising can be categorized as immoral activity and he is providing four advertising properties: false, misleading, irrelevant and bad taste advertising. In general, advertisement is linked with ethics and moral norms of owners and managers.

\section{Ethics for Owners and Managers and the Corporation}

Owners, managers and works are interested parties in every company, and they share the same goals and their future is depending from the success of the company. All of them are giving efforts to produce and to create a profit that is shared between them. However, the owners and managers are earning more than workers since they have larger responsibilities. Success of companies depends on the performance of managers and they are aware of this fact. Managers have lot of power and in many cases managers are misusing this power in order to create pers onal profit and in a same time they are "violating the trust the company and its employees put in them, and in general to work various kinds of evil" (Narveson, 1988, p.71). For example based on author personal experience, there are cases when a manager is blocking their staff to be promoted in other departments, because they are depending on their staff. In this way managers are protecting their own interest and they are abusing their power. Managers can also be blocked by internal corporate rules and regulations; and according to Narveson, (1988), "sometimes this is happening because personal goals of managers conflict with the company requirements and when ethical principles conflict with them" (p.74).

Manager's responsibility is to create profit for owners, and they are doing this by following the rules and applicable laws. Owners or shareholders have a crucial role on behavior of company. Goodpaster (n.d) states that" Stakeholder thinking, in other words, is a way of "operationalizing" corporate conscience from the perspective of the organization within its specific circumstances. In this respect, stakeholder thinking is the corporate analogue to subjective thinking on the part of individual conscience" (p.9) while Frederick, (1994) states that" the fundamental idea embedded in corporate social responsibility is that business operations have an obligation to work for social betterment. This obligation is incurred and acts as a constant function throughout all phases -mainstream and peripheralof the company's operations". (p.151). Since the corporates are operating within communities, they should also have community social responsibility, Caroll, (1991), is defining those responsibilities in a pyramid of ethic responsibilities that is shown in Figure 1. 


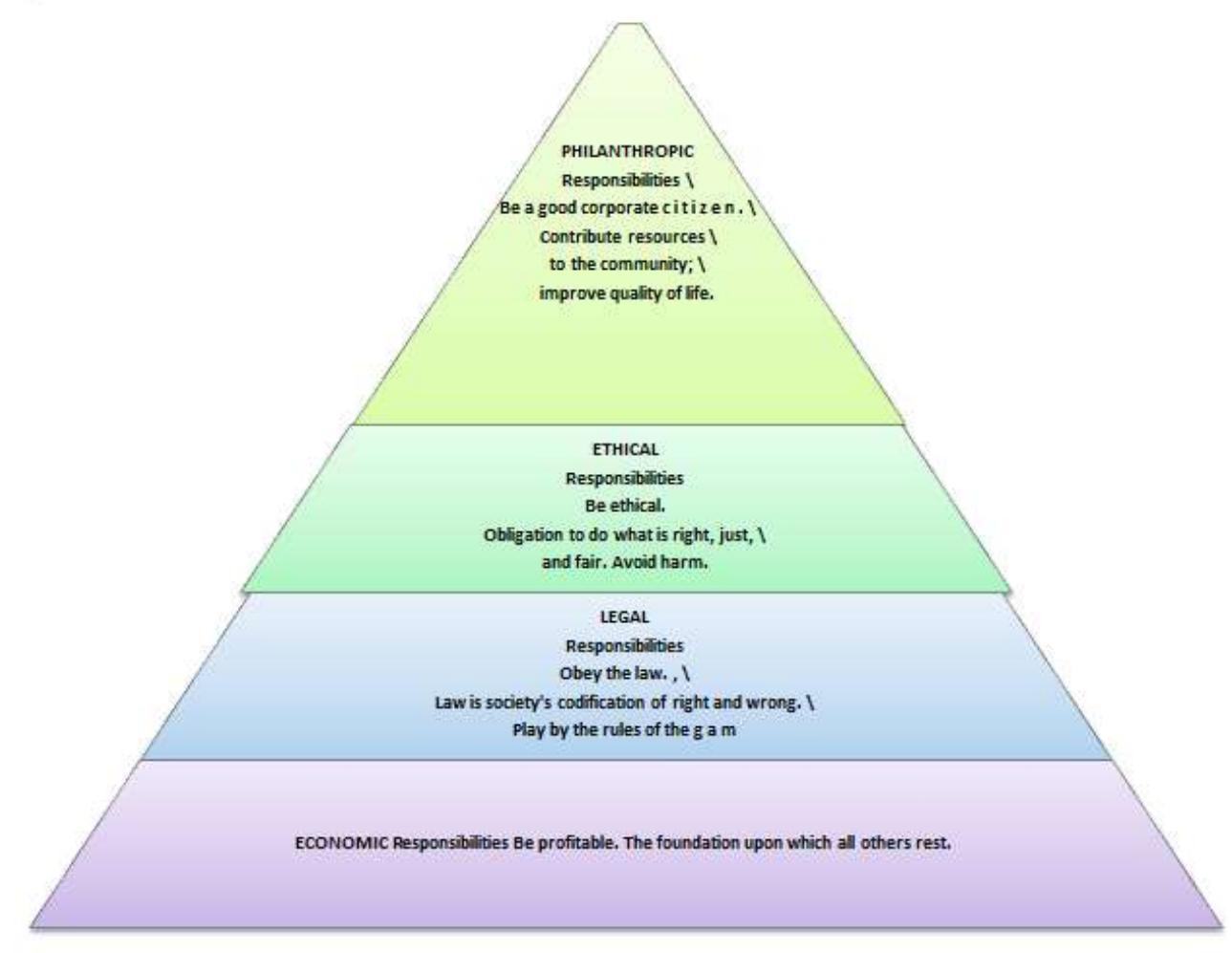

Fig 1, Pyramid of ethic responsibilities, adopted from Caroll, (1991), (p.42)

As an ethical components or responsibilities Caroll, (1991) states that "corporates should perform in a manner consistent with expectations of societal mores and ethical norms and it is important to recognize that corporate integrity and ethical behavior go beyond mere compliance with laws and regulations" (p.41). Another researcher, Goodpaster, defines three level of moral awarness for corpoations, individual, organizational and societal level.

Corporates should not be is olated from the community, in order to fulfill social responsibility corporated need to spend their own resources, theu will have benefits. Reasons why the coroprates are implementing social responsibility according Davis (1973) are: Long run self interest, public image, viability of business, avodiance of gouvernment regulation, stockholder interest, sense of backh anded, avalibility of resources, avoiding potential problems,

\section{Employee Rights and Duties and Employee Equity}

Because of better education system, globalization and competition, most of employees nowadays poses lot of skills like interpersonal, communication and self-management skills. Those skills are the resources that one employee possess and in this way employees can create their own competitive advantage. Depending from the industry and from the country individuals can earn different wages. Companies do not literally own their employees, but many companies consider their staff as a part on inventory. This is happening in third world countries because unemployment rate is high and employees do to not have any alternative. In other cases, employees are blocking thems elves because of their career anchors. Employees have right on good working conditions, however some kind jobs do not provide good working conditions but they are offering insurance in a case ofaccident. In some cas es the offered (pre agreed) compensation may be low, for example in authors case, if he is dying in his working place, the company will pay $263 €$ to his family. However different situation in in USA, Canada and in Western European countries, since employees' rights are regulated by the law. 
Kennedy, (2006) states that" When the Church claims an expertise in humanity, it means that it has a set of principles to offer to the human community according to which practical arrangements of all sorts may be evaluated for their potential benefit or harm to human persons. The first of these principles is that each and every member of the human species is a person possessed of an irreducible dignity, or value".(p.8). Companies that are recruiting them should take people's dignity and value in consideration. Evan that by law in many countries everybody should have the equal rights during the process of employment, this is not happening. There are still racial, political and religion differences that may prevent some people to be hired and promoted. For example, it is almost impossible for one person who declares publicly his homosexualorientation to get a government job in Rusia, or in author's country (republic of Kosovo) it is impossible to be employed in the government or to get promoted in some publicly owned company if that person is not member of specific political party.

\section{Conclusion}

Customers, consumers, owners and employees have an ethical relationship between them. However, the ethic that is implemented by them is related to personal values and beliefs. Companies have their code of conduct, where they had defined those relationships. Customers and consumers should be properly informed regarding the purchased products and they should not be misinformed. The communication between customers and companies is conducted also by advertisement. When companies are, adverting their products and services, they are sending selected information and ethic should be used also here. Advertisement should not be used to mislead or to misinform customers.

Stakeholders and stockholders have moral rights on the corporation, but those rights are not the same. While stockholders have moral rights and obligations to the comunity, stakeholders have rights and obligations to corporate. Stockholders have community social responsibility and many corporates are investing their own resources and knowledge in order to fulfill this responsibility.

Corporates are regulating their relationship with employees by signing themcontracts that are according to the law, but corporates have also moral obligation to their staff. Companies need to create proper working conditions and they are also responsible for employees' pension funds. Corporates should not discriminate their staff and they should pay equal salaries regardless employees race, gender, political or religion beliefs.

\section{References}

1. Carroll, A. B. (1991). The pyramid of corporate social responsibility: toward the moral management of organizational stakeholders. Business Horizons, 39-48.

2. Davis, K. (1973). The case for and against bussines assumption for social responsibilities. 16(2), 312-322.

3. Frederick, W. C. (1994). From CSR1 to CSR2 the maturing of business and society thought. Business and Society, 33(2), 150-164.

4. Goodpaster, K. E. (n.d.). Stakeholders and the common good: a polarity within corporate conscience. 1-16.

5. Kennedy, R. G. (2006). Corporations, common goods and human persons. 4(1).

6. Narveson, J. (1988). Ethics in the business and professional life 